\title{
CONDYLOMA LATA IN A 21-YEAR-OLD MALE TREATED WITH DOXYCYCLINE: A CASE REPORT
}

\author{
Hendra Minarto \\ Pieter L. Suling \\ Department of Dermatovenereology Faculty of Medicine \\ University of Sam Ratulangi Manado \\ Email: hendraminarto@gmail.com
}

\begin{abstract}
Abstrak: Kondiloma lata merupakan salah satu manifestasi sifilis sekunder yang disebabkan oleh Treponema pallidum. Manifestasi klinis kondiloma lata berupa papulpapul berwarna putih atau keabuan pada daerah tubuh yang hangat dan lembab. Sifilis memerlukan perhatian serius karena penyakit ini merupakan salah satu faktor risiko transmisi human immunodeficiency virus (HIV) di seluruh dunia. Kami melaporkan satu kasus kondiloma lata pada seorang laki-laki berusia 21 tahun di daerah penis, skrotum, perineal, dan perianal sejak 2 bulan lalu, yang diterapi dengan doksisiklin 2 x $100 \mathrm{mg}$ selama 30 hari. Pada pemeriksaan serologik awal didapatkan hasil reaktif untuk tes VDRL (1/256), tes RPR (1/512) dan tes TPHA (1/5120). Perbaikan signifikan terlihat setelah 30 hari terapi doksisiklin dimana semua lesi menghilang. Pemeriksaan serologik 3 bulan setelah awal terapi menunjukkan penurunan titer sebanyak empat kali lipat untuk tes VDRL (1/64), tes RPR (1/128), dan enam kali lipat untuk tes TPHA (1/640). Simpulan: Telah dilaporkan kasus kondiloma lata dengan diagnosis ditegakkan berdasarkan anamnesis, pemeriksaan fisik, dan serologik. Terapi doksisiklin selama 30 hari memberikan hasil yang memuaskan. Pemeriksaan serologik harus dilakukan pada bulan ke-6 dan 12 untuk monitoring keberhasilan terapi.
\end{abstract}

Kata kunci: kondiloma lata, sifilis sekunder, Treponema pallidum, doksisiklin

\begin{abstract}
Condyloma lata is one manifestation of secondary syphilis caused by Treponema pallidum. It is described clinically as multiple whitish or gray papules found in warm and moist areas. Syphilis requires serious attention since it still remains a risk factor of human immunodeficiency virus (HIV) transmission all around the world. We reported a case of a 21-year-old male suffered from condyloma lata on his penile, scrotal, perineal, and perianal regions for 2 months and treated with 30 days course of $100 \mathrm{mg}$ doxycyline two times daily. Early serologic examinations revealed reactive values of VDRL test (1/256), RPR test (1/512), and TPHA test (1:5120). Significant improvement was observed after 30 days course of doxycyline therapy where all lesions have resolved. Further serologic examinations as follow up showed a fourfold titre decrease of VDRL test (1/64), RPR test (1/128) and sixfold titre decrease of TPHA test (1/640) 3 months after the initial therapy. Conclusion: The diagnosis of condyloma lata in this case was established based on anamnesis, physical examination, and serologic findings. Treatment with doxycycline gave satisfactory result. Serologic examination as follow up needs to be performed at 6 and 12-months after the initial treatment to monitor the success of therapy.
\end{abstract}

Keywords: condyloma lata, secondary syphilis, Treponema pallidum, doxycycline. 